\title{
Evaluation of sealing between abutment and inner connection of cone morse dental implant: microgaps between implant and abutment
}

\author{
- Derivaldo Moura Gois Filho Department of Dentistry, Federal University of Sergipe, Aracaju, SE, Brazil • Vanessa Tavares \\ de Gois-Santos Department of Dentistry, Federal University of Sergipe, Aracaju, SE, Brazil • Ronaldo Santos Silva Physics \\ Department, Federal University of Sergipe, Aracaju, SE, Brazil • Antônio Carlos Marqueti Department of Dentistry, \\ Federal University of Sergipe, Aracaju, SE, Brazil • Arthur Rodriguez Gonzalez Cortes Department of Stomatology, School \\ of Dentistry, University of São Paulo, São Paulo, SP, Brazil • Cleverson Luciano Trento Department of Dentistry, Federal \\ University of Sergipe, Aracaju, SE, Brazil
}

ABSTRACT | Introduction: The adaptation of prostheses fixed over implants involves biomechanical aspects that are directly associated with treatment success. Objective: The aim of this in vitro study was to evaluate the presence of microgaps in the abutment/inner connection interface of cone morse dental implants. Materials and methods: Two groups of implants were analyzed. The first group $(n=16)$ employed single-manufacturer dental implants and abutments, whereas the second group $(n=16)$ combined multi-manufacturer materials. The sets were analyzed through scanning electron microscopy, wherein microgaps between the implant connection and the abutment were observed. Results: Group 1 had an average microgap of $5.69 \mu \mathrm{m}(\mathrm{SD} \pm 8.46 \mu \mathrm{m})$. Group 2 had an average microgap of $1.24 \mu \mathrm{m}(\mathrm{SD} \pm 0.44 \mu \mathrm{m})$. A significant difference was found between the two groups $(p=0.002)$. Conclusion: Within the limitations of this study, results suggest that the group formed by multi-manufacturer implants and abutments (group 2) had smaller microgap values, and, therefore, a higher in vitro adaptation of components.

DESCRIPTORS | Dental Implants; Dental Abutments; Scanning Electron Microscopy.

RESUMO | Avaliação da vedação entre pilar e conexão interna do implante dentário do Cone Morse: micro intervalos entre o implante e o pilar - Introdução: Aspectos biomecânicos relacionados à adaptação de próteses fixas sobre implantes estão diretamente associados ao sucesso do tratamento. Objetivo: Avaliar in vitro a presença de microgaps na união formada pelo pilar e a conexão interna do implante dentário Cone Morse. Materiais e método: Dois grupos de implantes foram analisados. O primeiro grupo $(\mathrm{n}=16)$ utilizou materiais (implantes e pilares) do mesmo fabricante, enquanto o segundo grupo $(\mathrm{n}=16)$ utilizou materiais de diferentes fabricantes. Os conjuntos foram enviados para o microscópio eletrônico de varredura, onde foram tomadas as medidas dos microgaps formados entre a conexão do implante e o pilar. Resultados: Os resultados obtidos foram submetidos à avaliação estatística (Mann-Whitney-U) das medidas de dispersão e à tendência central dos valores (desvio padrão e médio). No grupo 1, a média encontrada foi de 5,69 $\mu \mathrm{m}$ e o desvio padrão (SD) foi de 8,46 $\mu \mathrm{m}$. O grupo 2 apresentou média de 1,24 $\mu \mathrm{m}$ e SD: o,44 $\mu \mathrm{m}$. A diferença encontrada foi estatisticamente significativa $(p=0,002)$. Conclusão: Dentro da limitação deste estudo, os resultados indicam que o grupo formado por implante e abutment de diferentes fabricantes oferece menores valores de microgaps e, portanto, uma melhor adaptação in vitro de componentes.

DESCRITORES | Implantes Dentários; Dente Suporte; Microscopia Eletrônica de Varredura.

CORRESPONDING AUTHOR | - Cleverson Luciano Trento Department of Dentistry, Federal University of Sergipe, Aracaju, SE, Brazil • Rua Claudio Batista, n/n Cidade Nova, Aracaju, SE, Brazil -49060-108 E-mail: cleverson@ufs.br

- Received June 29, 2018 • Accepted July 19, 2018

- Dol http://dx.doi.org/10.11606/issn.2357-8041.clrd.2018.147797 


\section{INTRODUCTION}

One of the main reasons for the maladjustment of dental implants is the presence of microgaps. According to biomechanical analyses, microgaps in implant/abutment connections lead to micromovements, which in turn may cause biological tissue alterations. Regardless of location and type of connection (i.e., inner or external), it is important to achieve a better stress distribution between components (i.e., implant and prosthesis). Such distribution, in turn, prevents bacterial colonization on the connection. ${ }^{(1)}$ In this context, manufacturers of dental implants and abutments try to reduce bacterial infiltration by increasing the precision and quality control of their products, in order to minimize microgaps and increase stability between the parts. ${ }^{(2-4)}$

The sealing of implant/abutment cone morse connections is reported in the literature as a hermetic mechanism preventing penetration of microorganisms by promoting a complete bonding of the interface. ${ }^{(5)}$ To prevent resorption associated with the implant's platform, cone morse connections (also known as "Morse taper" connections) have been developed with the aim of sealing the abutment/implant interface. Such sealing should prevent bacterial infiltration and problems caused by bacterial toxins, such as inflammatory processes, bone resorption, fatigue of the implant/abutment set and, ultimately, fracture of components. ${ }^{(6)}$

Koutouzis et al. analyzed microgap bacterial contamination within cone morse-like connections between implant and abutment. After 500,000 $15 \mathrm{~N}$ load cycles, the authors observed higher contamination in the group with larger abutment microgaps. They concluded that the connection's design could affect the risk of bacterial invasion through microgaps in the implant/abutment union, after the set was subjected to dynamic loads. ${ }^{(7)}$
The possibility of forming the implant/abutment set with components from different manufacturers has been well described in the literature, ${ }^{(8)}$ including recent studies. ${ }^{(9)}$ The feasibility of this type of combination has been ascertained, and besides, it may produce better results than single-manufacturer sets.

Thus, the aim of this research was to evaluate the in vitro presence of microgaps in the bonding between the inner connection surface of a cone morse implant and its abutment, measuring the formed microgap, using abutments from a single or multiple manufacturers.

\section{MATERIAL AND METHODS}

This in vitro study assessed the bonding between dental implant and abutment, using scanning electron microscopy (SEM). It took place at the Physics and Material Engineering departments of the Federal University of Sergipe.

Samples were divided into 2 groups (32 implants +32 abutments). All components were made out of titanium. The first group $(n=16)$ used materials (dental implant and abutment) from a single manufacturer: Neodent ${ }^{\circledR}$ (Curitiba, PR, Brazil). The second group ( $n=16)$ used materials from multiple manufacturers: dental implants from Neodent ${ }^{\circledR}$ (Curitiba, PR, Brazil), and abutments from Singular ${ }^{\circledR}$ (Parnamirim, RN, Brazil).

Preparation of samples began by placing implants on their aluminum bases, with the help of a bench vise, through a manual surgical torque meter (Neodent ${ }^{\circledR}$, reference number 104.027, $45 \mathrm{~N}$ torque). Abutments were then installed over implants using a manual prosthesis torque meter (Neodent ${ }^{\circledR}$ 104.050), according to the instructions of the respective manufacturers. A $32 \mathrm{~N}$ torque was applied to abutments in groups 1 and 2, and after 30 minutes the same torque was applied to all components.

Implants and their respective attached abutments were fixed to a hard-surfaced, immobile 
bench tilted at a $25^{\circ}$ angle, in order to perform SEM testing (electron emitter filament: $22 \mathrm{~mm}$ ). The assembly of implants and their abutments was done right before SEM image evaluation. Room temperature was around $20^{\circ} \mathrm{C}$, and air humidity was lower than 60\% (assessed through a digital thermometer). The SEM device was adjusted to an accelerating voltage of $15 \mathrm{kV}$. The presence of microgaps between the inner connections of implants and abutments was thus evaluated.

The employed SEM device was a JEOL JCM-5700 CARRY SCOPE (Massachusetts, USA). SEM images were obtained using the secondary electrons mode.

Measurements were done by a single researcher, using a $5000 \times$ magnifier at a micrometer scale $(\mu \mathrm{m})$. Register points for assessment were the visible regular border of the inner connection of the cone morse implant, and the visible border of the abutment surface. A perpendicular line was traced between both.

All obtained information was codified and inserted into a database. The Shapiro-Wilk test was used to verify normality of data distribution. Median Comparison between the two groups was performed via the Mann-Whitney U test. The analysis' level of significance was $5 \%(p<0.05)$. Data were analyzed using SPSS software version 20.0, and Minitab version 17.

\section{RESULTS}

Normality was rejected, according to ShapiroWilk test $(p<0.05)$. Microgap quantification results are in Table 1 (minimum, maximum, median and standard deviation values). The hypothesis of equality between the two tested groups was rejected, according to Mann-Whitney test $(p=0.002)$. Values of microgaps found on samples of the two groups were evaluated through central tendency measurements and dispersion measurements. Group 1 showed higher microgap values, therefore greater dispersion (Figure 1).
Table 1 | Number of evaluated samples and their respective minimum, maximum, median, and standard deviation values (for each group).

\begin{tabular}{c|c|c} 
& Group 1 $(\mu \mathrm{m})$ & Group 2 $(\mu \mathrm{m})$ \\
\hline$n$ & 16 & 16 \\
\hline Minimum & 0.89 & 0.71 \\
\hline Maximum & 28.39 & 2.04 \\
\hline Median & 5.6913 & 1.2469 \\
\hline $\begin{array}{c}\text { Standard Deviation } \\
(\mathrm{SD})\end{array}$ & \pm 8.4623 & \pm 0.44509 \\
\hline
\end{tabular}

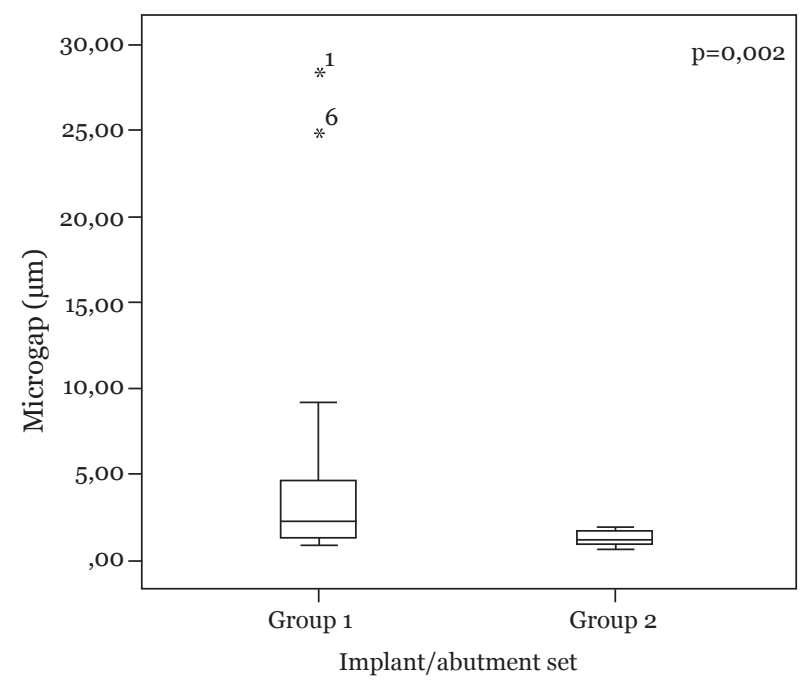

Figure 1 | Boxplot graph showing a greater dispersion of values in group 1.

\section{DISCUSSION}

According to the literature, the quality of implant/ abutment connections plays an important role in maintaining dental implants. Evidence shows that microgaps may lead to inflammatory processes due to bacterial infiltration, with a subsequent circulation of toxins from the inner part of the connection to the peri-implantar tissues. This physiopathological process takes place due to bone resorption associated with the implant. Cone morse connections have been described as able to prevent such conditions. ${ }^{(6)}$

Scanning electron microscopy (SEM) is the most indicated technique for microscopically assessing surfaces and structures (in this case, our microgaps), with micrometer-scale quantification. 
Besides its high resolution, an important advantage of SEM is its great focus depth, allowing for the obtention of tridimensional topographic images with good quality and resolution. In this study, scanning electron microscopy was employed due to its superior precision and simplicity in measuring the microgaps between the two parts of the implants, when compared to other techniques (computerized tomography, computer-aided design, and computer-aided manufacturing). Another advantage of the technique is that the analyzed samples can be kept at a fixed and predetermined position. . $7,10,11)$

Images obtained through SEM visually reveal the presence of microgaps in the interface between the dental implant (cone morse-type inner connection) and the abutment surface, where our measurements were taken (Figure 2). External irregularities in connection and contact areas adjacent to implant and abutment were also observed in many samples (Figure 3). The presence of these irregularities points to machining defects of the manufacturing process.
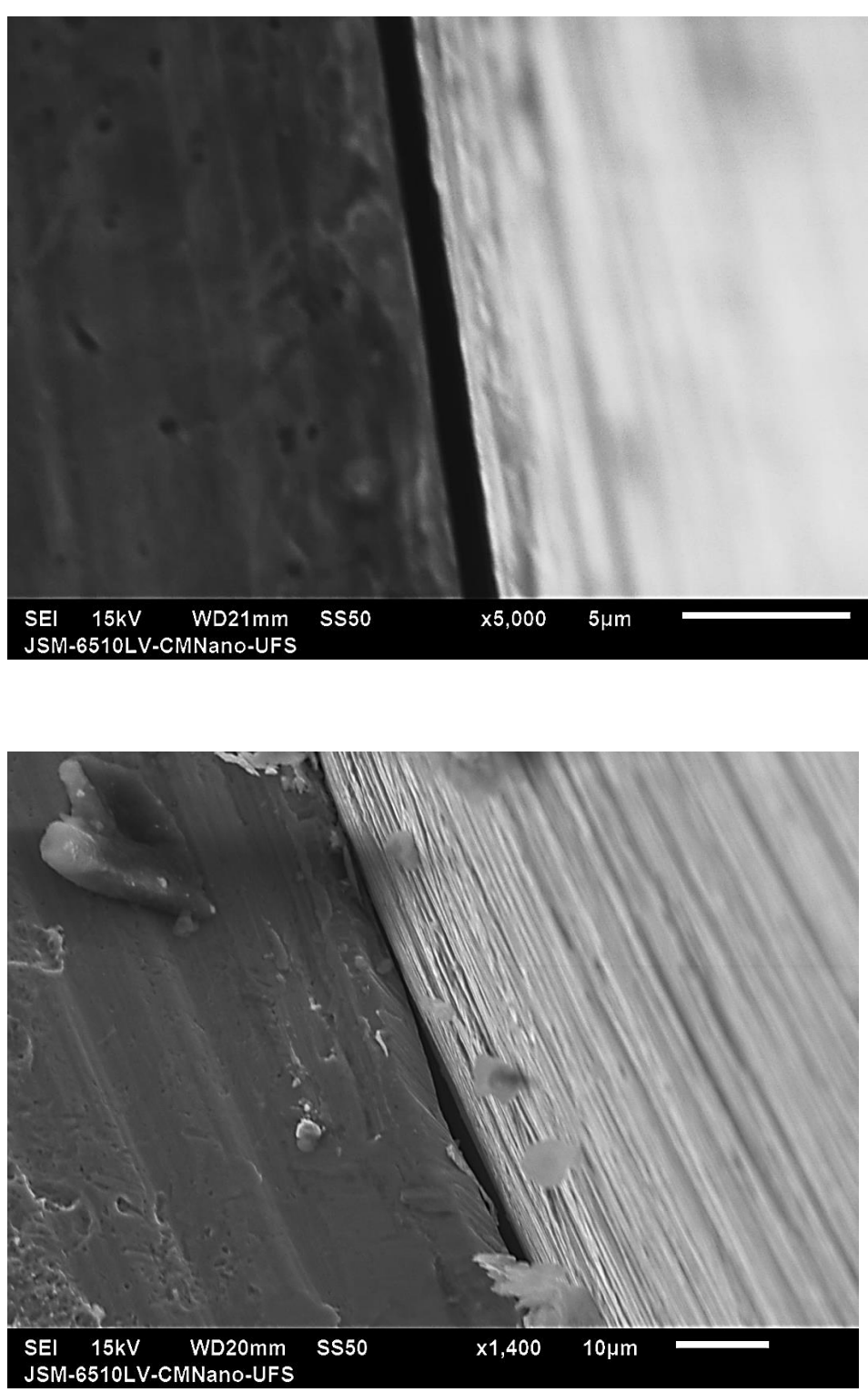

Figure 2 | Microgap disclosure (SEM: 5000×) on implant and abutment connection interface.

Figure 3 | SEM (1400x) image of imperfections on the external surface of the dental implant platform. 
Maladjustments from machining defects in implants and abutments lead to micromovements between these two structures, resulting in material fatigue due to masticatory loads. ${ }^{(12,13)}$ The consequences of maladjustment and microgap size may vary depending on connection and abutment imperfections. ${ }^{(2)}$ In any case, this condition determines a higher instability of bonding between the components, with a decrease of parts' mechanical resistance.

While the bonding between implant and abutment through cone morse-type connections is described in the literature as a hermetic mechanism that completely seals the interface, preventing microorganism penetration, ${ }^{(5)}$ results obtained in this study clearly show-even visually, through SEM analysis-microgaps in this supposedly 'hermeticallysealed' interface. According to these results, all samples $(n=32)$ had microgaps, disagreeing with the literature's premise of cone morse-type connections as perfectly sealed interfaces.

Preliminary studies have already observed the presence of these microgaps in abutment/implant interfaces using components from the same manufacturer, with $2-7 \mu \mathrm{m}^{(14,15)}$ and $40-65 \mu \mathrm{m}^{(16)}$ values. However, these studies evaluated the external hexagon connection type. In comparison to the results obtained here (for cone morse-type connections), we verified that microgap values for group 2 were much lower than the ones deemed acceptable by the literature, especially in contrast to the external hexagon connection type. This microgap difference between connection types may be related to their distinct sealing mechanisms.

The feasibility of combining implants and abutments from different manufacturers has already been described in the literature. ${ }^{(17)}$ Using implants with external hexagon connections from 5 different manufacturers $\left(\right.$ Nobel $^{\circledR}$, BTI $^{\circledR}$, Bioner $^{\circledR}$, Biomet $^{\circledR}$, and Biofit $\left.{ }^{\circledR}\right)$, a study evaluated the presence of microgaps when employing single-brand or multi-brand combinations of implants and abutments. Microgaps were quantified using SEM. The authors concluded that there were microgaps in all samples, with the lowest microgap values obtained (after application of the manufacturer-recommend torque) from the following implant-abutment brand combinations: Biomet $^{\circledR}-$ Bioner $^{\circledR}$, Biomet ${ }^{\circledR}-$ BTI, Biomet ${ }^{\circledR}-$ Nobel $^{\circledR}$, Nobel $^{\circledR}-{ }^{-B i o m e t}{ }^{\circledR}$, and Nobel $^{\circledR}-$ Bioner $^{\circledR}$. In the case of implants and abutments from the same manufacturer, the best results were provided by Nobel ${ }^{\circledR}$, with $<2 \mu \mathrm{m}$ microgap values. The authors concluded that the combination of different manufacturers of implant and abutments was feasible, since microgap values lower than $10 \mu \mathrm{m}$ do not produce deleterious effects. We found similar values in group 2 (implant and abutment from different brands), with a minimum microgap of $0.71 \mu \mathrm{m}$ and a maximum of $2.04 \mu \mathrm{m}$.

In a study with three different implant brands (Bicon ${ }^{\circledR}$, Straumann ${ }^{\circledR}$, Ankylos ${ }^{\circledR}$ ) and their respective abutments, an analysis of the contact area between the abutment and the "cone-type" inner connection was performed, also looking for microgaps. ${ }^{(6)}$ Employing microtomography (Micro$\mathrm{CT}$ ), the authors found gaps greater than $10 \mu \mathrm{m}$, but were unable to find microgaps in three of the evaluated samples. This stands in disagreement with our results, which found median microgaps of $5.6 \mu \mathrm{m}$ and $1.2 \mu \mathrm{m}$ (for groups 1 and 2 , respectively). Comparisons between the aforementioned study and ours, at least in respect to the size and presence of microgaps, are not relevant, considering that in this study the employed evaluation method was electron microscopy, and not microtomography. Micro-CT has a reduced magnification capability (only microgaps with values greater than $10 \mu \mathrm{m}$ are observable), while eventual distortions during the image-rebuilding process can decrease the accuracy of results. According to the authors, brands whose samples had greater contact surface were, in decreasing order: Bicon ${ }^{\circledR}$, Ankylos ${ }^{\circledR}$, and Straumann ${ }^{\circledR}$. In another study, interface microgaps were found even 
when then implant/abutment set was comprised of components from different manufacturers. ${ }^{(18)}$

Technical limitations of this study notwithstanding, it found interface microgaps in all the studied samples $(n=32)$. By evaluating the variances obtained from groups 1 and $2(5.6 \pm 8.4 \mu \mathrm{m}$ and $1.2 \pm 0.44 \mu \mathrm{m}$, respectively), we inferred that the discrepancies in microgap values have to be attributed to the abutments, since abutments from the same implant manufacturer were used in both groups. Nevertheless, group 2 showed significant higher adaptation values $(p=0.002)$.

\section{ACKNOWLEDGEMENTS}

The authors thank Neodent ${ }^{\circledR}$ (Curitiba, PR, Brazil) and Singular ${ }^{\circledR}$ (Parnamirim, RN, Brazil), for providing implants and abutments, contributing to the development of the science of implantology.

Special thanks to the Federal University of Sergipe, for providing the material engineering laboratories and electron microscopy equipment necessary for this study's realization.

\section{REFERENCES}

1. Coelho PG, Sudack P, Suzuki M, Kurtz KS, Romanos GE, Silva NRFA. In vitro evaluation of the implant abutment connection sealing capability of different implant systems. J Oral Rehabil. 2008;35(12):917-24.

2. Silva-Neto JP, Prudente MS, Carneiro TAPN, Nóbilo MAA, Penatti MPA, Neves FD. Micro-leakage at the implant-abutment interface with different tightening torques in vitro. J Appl Oral Sci. 2012;20(5):581-7.

3. Ribeiro CG, Maia MLC, Scherrer SS, Cardoso AC, Wiskott HWA. Resistance of three implant-abutment interfaces to fatigue testing. J Appl Oral Sci. 2011;19(4):413-20.

4. Ricomini Filho AP, Fernandes FSF, Straioto FG, Silva WJ, Del Bel Cury AA. Preload loss and bacterial penetration on different implant-abutment connection systems. Braz Dent J. 2010;21(2):123-9.

5. Dibart S, Warbington M, Su MF, Skobe Z. In vitro evaluation of the implant-abutment bacterial seal: the locking taper system. Int J Oral Maxillofac Implants. 2005;20(5):732-7.
6. Meleo D, Baggi L, Di Girolamo M, Di Carlo F, Pecci R, Bedini R. Fixture-abutment connection surface and micro-gap measurements by $3 \mathrm{D}$ micro-tomographic technique analysis. Ann Ist Super Sanita. 2012;48(1):53-8.

7. Koutouzis T, Wallet S, Calderon N, Lundgren T. Bacterial colonization of the implant-abutment interface using an in vitro dynamic loading model. J Periodontol. 2011;82(4):613-8.

8. Binon PP. Implants and components: entering the new millennium. Int J Oral Maxillofac Implants. 2000;15(1):76-94.

9. Gross M, Abramovich I, Weiss EI. Microleakage at the abutment-implant interface of osseointegrated implants: a comparative study. Int J Oral Maxillofac Implants. 1999;14(1):94-100.

10. Nascimento C, Pedrazzi V, Miani PK, Moreira LD, De Albuquerque RF Jr. Influence of repeated screw tightening on bacterial leakage along the implant-abutment interface. Clin Oral Implants Res. 2009;20(12):1394-7.

11. Solá-Ruíz MF, Selva-Otaolaurruchi E, Senent-Vicente G, González-de-Cossio I, Amigó-Borrás V. Accuracy combining different brands of implants and abutments. Med Oral Patol Oral Cir Bucal. 2013;18(2):e332-6.

12. Heckmann SM, Linke JJ, Graef F, Foitzik CH, Wichmann MG, Weber HP. Stress and inflammation as a detrimental combination for peri-implant bone loss. J Dent Res. 2006;85(8):711-6.

13. Broggini N, McManus LM, Hermann JS, Medina R, Schenk RK, Buser D, et al. Peri-implant inflammation defined by the implant-abutment interface. J Dent Res. 2006;85(5):473-8.

14. Tsuge T, Hagiwara Y, Matsumura H. Marginal fit and microgaps of implant-abutment interface with internal anti-rotation configuration. Dent Mater J. 2008;27(1):29-34.

15. Piattelli A, Scarano A, Paolantonio M, Assenza B, Leghissa GC, Di Bonaventura G, et al. Fluids and microbial penetration in the internal part of cement-retained versus screw-retained implantabutment connections. J Periodontol. 2001;72(9):1146-50.

16. Scarano A, Assenza B, Piattelli M, Iezzi G, Leghissa GC, Quaranta A, et al. A 16-year study of the microgap and their abutments between 272 human titanium implants. J Oral Implantol. 2005;31(6):269-75.

17. Sartori IADM, Ribeiro RF, Francischone CE, Mattos MGC. In vitro comparative analysis of the fit of gold alloy or commercially pure titanium implant-supported prostheses before and after electroerosion. J Prosthet Dent. 2004;92(2):132-8.

18. Berberi A, Tehini G, Rifai K, Bou Nasser Eddine F, Badran B, Akl H. Leakage evaluation of original and compatible implantabutment connections: in vitro study using Rhodamine B. J Dent Biomech. 2014;5:1758736014547143. 